\title{
Soil quality indicators in an Andisol under different tree covers in disturbed Nothofagus forests
}

\author{
Marianela Alfaro ${ }^{1,2}$, Francis Dube ${ }^{2 *}$, and Erick Zagal ${ }^{3}$ \\ ${ }^{1}$ Universidad de Costa Rica, Facultad de Ingeniería, Casilla 11501-2060, San José, Costa Rica. \\ ${ }^{2}$ Universidad de Concepción, Facultad de Ciencias Forestales, Victoria 631, Concepción, Chile. \\ *Corresponding author (fdube@udec.cl). \\ ${ }^{3}$ Universidad de Concepción, Facultad de Agronomía, Av. Vicente Méndez 595, Chillán, Chile.
}

Received: 3 October 2017; Accepted: 16 November 2017; doi:10.4067/S0718-58392018000100106

\begin{abstract}
Non-systemic logging, cattle browsing and grazing with the site natural vegetation can modify tree covers in native forests and alter the quantity and quality of organic matter entering the soil and hence its overall quality. The objective of this study was to evaluate the effect of modifying tree covers by uncontrolled logging and grazing processes on soil quality, in a mature and unmanaged roble (Nothofagus obliqua (Mirb.) Blume) forest. Soil quality was evaluated under partly-closed (PC), partly-open (PO), and open (OP) forest covers, and two soil depths. The indicators used were soil organic $\mathrm{C}(\mathrm{SOC})$, potential net $\mathrm{N}$ mineralization $(\mathrm{N}-\mathrm{min})$, and nitrification $\left(\mathrm{N}-\mathrm{NO}_{3}\right)$, soil microbial respiration (SMR), microbial biomass C (MBC), soil aggregates, and light fraction (LF). At 0-5 cm soil depth SMR and MBC in PC cover was approximately $12 \%$ higher than in PO and OP covers. For the same soil depth $\mathrm{N}$-min in PC cover was $68 \%$ and $95 \%$ higher than in $\mathrm{PO}$ and OP covers, respectively; and for $\mathrm{N}-\mathrm{NO}_{3} \mathrm{PC}$ cover was $45 \%$ higher than $\mathrm{PO}$ cover. OP tree cover presented a negative $\mathrm{N}-\mathrm{NO}_{3}$ (immobilization). Dry weight for LF fraction in OP cover (labile OM) was $90 \%$ and $67 \%$ lower respect PC and PO covers, respectively $(\mathrm{P}<0.05)$. The soil quality and the activity of its microbial processes were affected by alteration of tree cover, as well by the anthropic action of logging and extensive grazing, the soil in OP cover was the most affected.
\end{abstract}

Key words: Andisol, disturbed forest, Nothofagus obliqua, soil quality, temperate forest, tree covers.

\section{INTRODUCTION}

In the Biobío Region of Chile, second-growth roble (Nothofagus obliqua [Mirb.] Blume) forests have a high potential for timber production, and a series of related products such as fuelwood, particleboard, and lumber (Bergh and Promis, 2011). However, the forests are not only used to produce fuel and building materials, but also to feed cattle (cattle grazing with natural vegetation and browse), and as shelter to protect the animals in winter. In many cases, this multiple use is not in equilibrium with the limited potential of these forest ecosystems (Altamirano and Lara, 2010). Historically, unsustainable use of native forests has been observed, where the lack of management has predominated, the extractive patterns centered in the financial criterion, and the lack of specific regulations on the use of second growth forests for pasture (Lara et al., 2009). This lack of sustainable management constitutes an obstacle to the conservation of native forests, resulting in a dramatic fragmentation and, or reduction of native forests by indiscriminate logging, which together with cattle can severely impair the establishment and regeneration of natural vegetation, as well as cause soil compaction from trampling of the topsoil, and overstocking the cattle on the pastures (Lara et al., 2009; Dube et al., 2016). 
The reduction of forest cover and change of land use play a key role in global warming, biodiversity conservation, regulation of the hydrological cycle and soil degradation, and alter key processes which control soil biogeochemical cycles (Altamirano and Lara, 2010; Bergh and Promis, 2011).

Much of the soils where these second growth forests are found belong to the Andisol order, formed from volcanic ash and are characterized by a high soil organic matter (SOM) content, good physical properties, high water retention capacity, low bulk density ( 0.6 to $\left.0.9 \mathrm{~g} \mathrm{~cm}^{-3}\right)$, high allophanic content, and a slower decomposition of incorporated organic materials (Stolpe and Undurraga, 2016). Allophane is a group of clay minerals made up of silica, aluminum, and water in a chemical combination (Garrido and Matus, 2012).

Lara et al. (2009) indicate that the management of native temperate forest ecosystems should be oriented toward forest use by providing ecosystem services without losing biological diversity, and understanding soil biogeochemistry in the ecosystem is a prerequisite for sustainable forest management. Soil quality evaluation is very useful for determining the sustainability of soil use and management systems. The concept of soil quality is based on its multi-functionality. It is defined as the ability to function as part of an ecosystem (natural or anthropogenic) and maintain plant and animal productivity (Bastida et al., 2008). Soil organic matter (SOM) is a key soil quality attribute because it has far-reaching effects on physical, chemical, and biological properties; however, high SOM levels and the natural variability of soil make it difficult to measure the effect of short-term changes from soil use (Bastida et al., 2008; Zagal et al., 2009).

The labile SOM fractions are incompletely transformed animal, plant, and microorganism residues, and the primary source of humus. These fractions tend to be more sensitive to changes in soil management practices or environmental conditions than total SOM; they have therefore been established as early indicators of soil quality and land use change or contamination. These indicators include the microbial biomass and microbial respiration rate, particulate organic matter (POM), light fraction (LF), and soil C and N content in the fractions (Zagal et al., 2009; Paul, 2016).

Currently, most studies conducted in Chilean forests have focused on the study of biogeochemical parameters in pristine forests, and there are few biological and biochemical studies of soil in forested communities in the Andean zone of south central (Alvear et al., 2007; Rivas et al., 2009), especially specific studies in disturbed roble forests that describe the dynamics and quality of soils under different pasture and forest cover conditions. It is postulated that the alteration of the tree cover in $N$. obliqua forests, as well as the anthropic action of selective logging and extensive cattle grazing, will determine the quality of the soil and the activity of its microbial processes. Therefore, the objective of this study was to evaluate the effect of modifying tree covers by logging and grazing processes on soil quality of an Andisol, in a mature and disturbed N. obliqua forest.

\section{MATERIALS AND METHODS}

\section{Site description and characterization}

The study site is located at the "Ranchillo Alto", commune Yungay (3704' S, 71³9' W), Biobío Region, Chile (Figure 1), it covers approximately 653 ha. The prominent climate is warm temperate Mediterranean with a short dry season (<4-mo), with an average annual rainfall of $3000 \mathrm{~mm}$, and mean annual temperature of $13.5^{\circ} \mathrm{C}$ (Rivas et al., 2009). The site is located on volcanic soil (Andisol) (CIREN, 1999).

The "Ranchillo Alto" includes a large area of native forest, which is under heavy pressure from long-term and ongoing land uses that include cattle browsing and grazing with the site natural vegetation, and tree cutting for firewood, charcoal and timber. These processes strongly threaten overall biodiversity, soil quality and the very existence of the forest itself (Dube et al., 2016). Livestock raising is a common activity throughout the property, except for the areas with higher elevations and peaks. The state owned land that normally provides most of the animal forage is highly valued by the community since the majority of surrounding properties generally do not have the capacity to produce sufficient forage for livestock consumption throughout the year. Unfortunately, continual animal grazing also hinders the natural regeneration of trees in the more open sites, which eventually affects the quality and density of the roble stands. Intensive and illegal logging can also be found throughout the site, and a large proportion of the forest has already been disturbed and subsequently degraded (Dube et al., 2016). It is also 
Figure 1. Study site Ranchillo Alto state property.

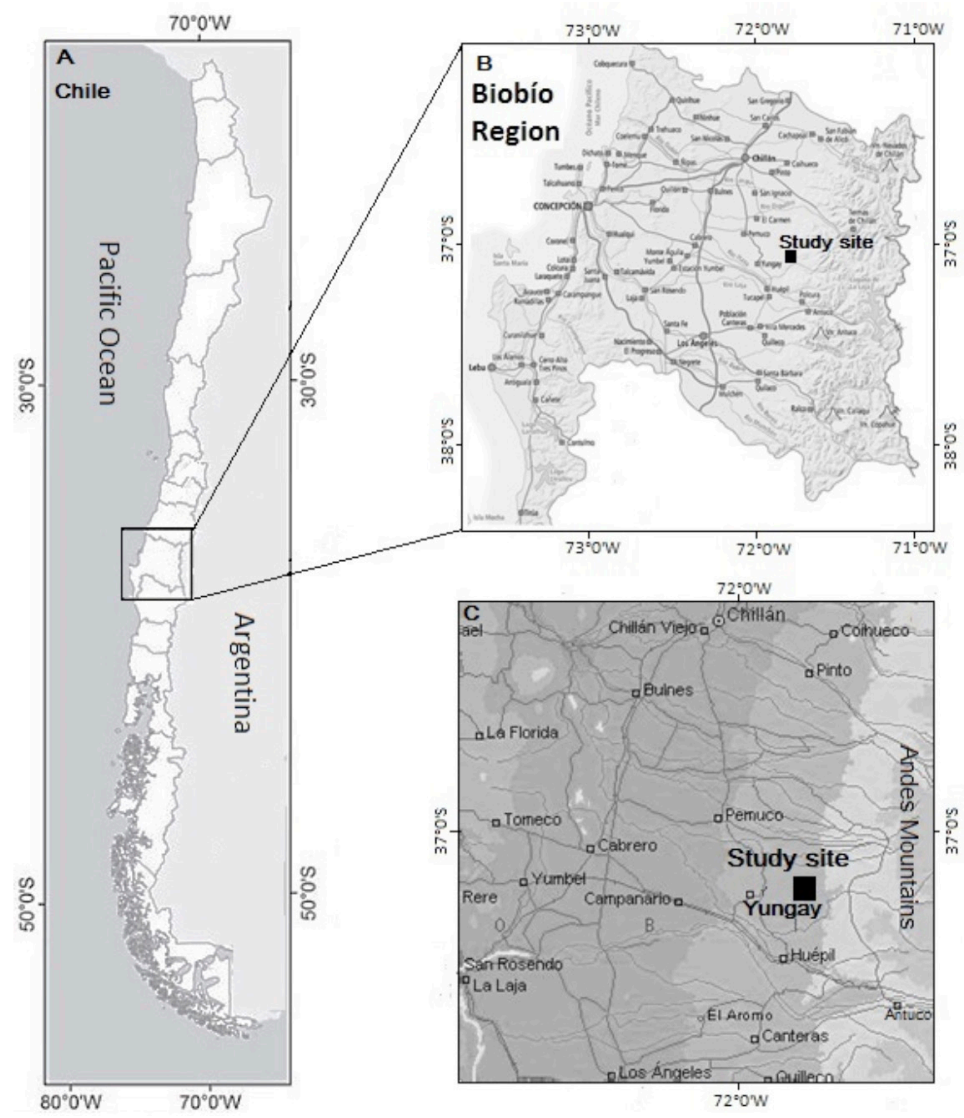

Map of Chile (A); Biobío Region (B); location of Ranchillo Alto (black square).

possible to see large areas where the forest is relatively open, or thin, and is comprised mainly of small trees, and with patches of degraded pastures that support livestock activity (Dube et al., 2016).

\section{Experimental design and sampling}

The tree cover level was evaluated in January 2015, using a Solariscope (SOL300, Behling, Berlín, Germany) (Annighöfer et al., 2015), that was placed at $1.5 \mathrm{~m}$ height above the ground, evaluations were done every $20 \mathrm{~m}$ in two parallel transects (1000 m length, $50 \mathrm{~m}$ spacing) with east-west orientation at each level of forest alteration (Dube and Stolpe, 2016). Three tree cover levels were determined: Open, partly open and partly closed (Table 1). For soil sampling, we established a randomized complete design with three replicates (plots) randomly distributed in each tree cover level. All plots had a size of $50 \times 50 \mathrm{~m}$ (following the recommendations of Donoso et al., 1984), a slope ranging from $10 \%$ to $15 \%$, a uniform aspect, and were located at similar elevations (1200 m a.s.l.) (Table 1).

Soil samples were done in November 2015. In each plot, soil sample were taken, composed of eight random sub samples at depths of 0-5 and 5-20 cm, following the recommendations of Dube et al. (2009). The samples were placed in polyethylene bags, were taken to the laboratory and were frozen at $-7^{\circ} \mathrm{C}$, later were unfrozen, air-dried and sieved using stainless steel sieve having $2 \mathrm{~mm}$ apertures, and stored at $4{ }^{\circ} \mathrm{C}$ for the analyses described below.

\section{Chemical and biological parameters}

Soil organic $\mathrm{C}, \mathrm{N}$ and $\mathrm{pH}$ analysis were performed at the soil depths of 0-5 and 5-20 $\mathrm{cm}$, and measured by dry combustion (Wright and Bailey, 2001). Soil pH was measured using a 1:2.5 mixture of soil and water (Sadzawka et al., 2006). 
Table 1. Tree covers descriptions and baseline information in the study site.

\begin{tabular}{|c|c|c|c|c|c|c|c|}
\hline Tree cover & Tree cover description & $\begin{array}{l}\text { Plot } \\
\text { size }\end{array}$ & Species & $\begin{array}{l}\text { Stocking } \\
\text { density }\end{array}$ & $\begin{array}{l}\text { Mean } \\
\text { DBH }\end{array}$ & $\begin{array}{l}\text { Basal } \\
\text { area }\end{array}$ & $\begin{array}{c}\text { Mean } \\
\text { HT }\end{array}$ \\
\hline Open (OP) & $\begin{array}{l}\text { Ground with } 85-95 \% \text { of external light } \\
\text { (average of area) }\end{array}$ & $\underset{50 \times 50}{\mathrm{~m}}$ & $\begin{array}{l}\text { Nothofagus obliqua, } \\
\text { Chusquea quila Kunth (quila) }\end{array}$ & $\begin{array}{l}\text { stems ha } \\
60\end{array}$ & $\mathrm{~cm}$ & $\begin{array}{c}\mathrm{m}^{2} \mathrm{ha}^{-1} \\
6.98\end{array}$ & $\mathrm{~m}$ \\
\hline Partly open (PO) & $\begin{array}{l}\text { Ground with } 65-75 \% \text { of external light } \\
\text { (average of area) }\end{array}$ & $50 \times 50$ & $\begin{array}{l}\text { N. obliqua, Lomatia hirsuta } \\
\text { Diels ex J.F. Macbr., Festuca spp., } \\
\text { Gaultheria phillyreifolia (Pers.) } \\
\text { Sleumer }\end{array}$ & 134 & 39 & 16 & 26 \\
\hline Partly closed (PC) & $\begin{array}{l}\text { Ground with } 45-55 \% \text { of external light } \\
\text { (average of area) }\end{array}$ & $50 \times 50$ & $\begin{array}{l}\text { N. obliqua, L. hirsuta, Festuca spp., } \\
\text { G. phillyreifolia }\end{array}$ & 258 & 32 & 20.7 & 20 \\
\hline
\end{tabular}

DBH: Diameter at breast height, HT: total height.

The soil microbial respiration (SMR) and microbial biomass C (MBC) were evaluated at the soil depths of 0-5 and 5-20 cm following the substrate-induced respiration (SIR) method described by Anderson and Domsch (1978). Three subsamples of $10 \mathrm{~g}$ dry soil for each soil sample were incubated to $22{ }^{\circ} \mathrm{C}$ for $24 \mathrm{~h}$, then placed in a gas-tight container suitable for $\mathrm{CO}_{2}$ headspace analysis. A concentration series of glucose amendments in liquid form to bring slightly dried soil to $60 \%$ water filled pore space (WPFS) (Linn and Doran, 1984) were added. The $\mathrm{CO}_{2}$ content was analyzed using a $\mathrm{CO}_{2}$ analyzer (LI-820, LI-COR, Lincoln, Nebraska, USA). The minimum concentration of glucose giving maximal respiratory response was added to replicate subsamples of soil, we used 5 and $10 \mu \mathrm{M} \mathrm{g}^{-1}$ dry soil for 0-5 $\mathrm{cm}$ and 5-20 $\mathrm{cm}$ depths, respectively. MBC was calculated using the Equation [1]:

$$
x=40.4 y+0.37
$$

where $x$ is total microbial biomass $\mathrm{C}\left(\mu \mathrm{g} \mathrm{C} \mathrm{g} \mathrm{g}^{-1}\right.$ dry soil) and $y$ is maximum initial rate of $\mathrm{CO}_{2}$ respiration $\left(\mathrm{mL} \mathrm{CO}_{2} \mathrm{~g}^{-1}\right.$ dry soil).

\section{Potential net $\mathrm{N}$ mineralization (N-min) and nitrification (N-NO$)$}

Three subsamples of $5 \mathrm{~g}$ dry soil were used as control, and three additional subsamples were incubated at $22{ }^{\circ} \mathrm{C}$ for $10 \mathrm{~d}$ at $60 \%$ WPFS (Linn and Doran, 1984), then put in a $150 \mathrm{~mL}$ plastic flask with $25 \mathrm{~mL}$ of $\mathrm{K}_{2} \mathrm{SO}_{4}(0.5 \mathrm{M})$ solution, were shake for $1 \mathrm{~h}$ at $180 \mathrm{rev} \mathrm{min}^{-1}$. The extract was decanted, filtered, and was analyzed by colorimetry using a UVvisible spectrophotometer (AA3, Bran+Luebbe, Norderstedt, Germany). Nessler reagent and sulfosalicylic reagent were used to determine $\mathrm{N}$-mineral as ammonium and nitrate (Alef, 1995). N-min and $\mathrm{N}-\mathrm{NO}_{3}$ were calculated using the Equation [2] and Equation [3] (Trap et al., 2009):

$$
\text { Potential net } N \text { mineralization }=\left[\left(N-N_{4}^{+}+N-N O_{3}\right)_{f}-\left(N-N_{4}^{+}+N-N O_{3}\right)_{i}\right] / T_{d}
$$

Potential net nitrification $=\left[\left(N-N O_{\overline{3}}\right)_{f}-\left(N-N O_{3}\right)_{\mathrm{i}}\right] / T_{d}$

where the subscripts $i$ and $f$ indicate concentrations measured before and after aerobic incubation, respectively, and $T_{d}$ indicates incubation time in days. $\mathrm{N}-\mathrm{min}$ and $\mathrm{N}-\mathrm{NO}_{3}$ were expressed as $\mu \mathrm{g} \mathrm{N} \mathrm{g}^{-1}$ dry soil d ${ }^{-1}$.

\section{Physical fractionation of SOM}

The SOM fractionation analysis was performed (0-5 and 5-20 cm depths) following the method described by Feller et al. (1991), $50 \mathrm{~g}$ soil was mechanically dispersed in a plastic bottle $(250 \mathrm{~mL})$ containing 10 glass beads $(6 \mathrm{~mm}$ diameter) and $180 \mathrm{~mL}$ distilled water, and shaken at 50 cycles $\min ^{-1}$ for $16 \mathrm{~h}$ using an overhead shaker (Hie-MIX Reax 2, Heidolph, Schwabach, Germany). The disrupted soil aggregates were then wet sieved using stainless steel sieves having 212 and $53 \mu \mathrm{m}$ apertures. The light fraction of organic matter (that were retained on the $212 \mu \mathrm{m}$ sieve) were separated by flotation. Soil samples were sieved according to separate the following fractions: macroaggregates $(>212 \mu \mathrm{m})$, mesoaggregates $(212-53 \mu \mathrm{m})$, and microaggregates $(<53 \mu \mathrm{m})$ (Dube et al., 2009). The fractions were dried at $50{ }^{\circ} \mathrm{C}$ for $48 \mathrm{~h}$ and weighed. The $\mathrm{C}$ and $\mathrm{N}$ contents of the light, intermediate, and heavy fractions were then measured by dry combustion (Wright and Bailey, 2001).

\section{Statistical analyses}

Two-way ANOVA was used to evaluate the effects of tree cover $(n=3)$ and soil depth $(n=2)$ on the dependent variables $\mathrm{SOC}, \mathrm{N}, \mathrm{C} / \mathrm{N}, \mathrm{pH}, \mathrm{SMR}, \mathrm{MBC}, \mathrm{N}-\mathrm{min}, \mathrm{N}_{-} \mathrm{NO}_{3}(\mathrm{P}<0.05)$. Three-way ANOVA was used to evaluate the 
effects of tree cover $(n=3)$, soil depth $(n=2)$, and soil fraction $(n=4)$ on the dependent variables dry weight of soil fractions, organic $\mathrm{C}$ and $\mathrm{N}$ content in the soil fractions. Normality (Kolmogorov-Smirnov test) and homoscedasticity of variance (Levene's test) were evaluated prior to analysis. Logarithmic transformations were performed when these assumptions were not met. Tukey's test was used for the comparison of means for tree covers, and Student's $t$ test for the comparison of soil depths, with a significance level of $95 \%$. Statistical analysis was performed with the program R Project for Statistical Computing (version 3.2.5, R Foundation for Statistical Computing, Vienna, Austria).

\section{RESULTS AND DISCUSSION}

\section{General chemical parameters}

Tree cover and soil depth presented a significant effect on the SOC, N, only soil depth on the pH, and there was nonsignificant effect on the $\mathrm{C} / \mathrm{N}$ ratio (Table 2). There was no interaction between tree covers and depth of soil $(\mathrm{P}<0.05)$.

SOC in the PC tree cover was higher (7\%) than in PO and OP tree covers; PO and OP tree covers did not show differences (Table 3). SOC was higher at $0-5 \mathrm{~cm}$ soil depth. N content was no different between PC and PO tree covers, nor between $\mathrm{PO}$ and $\mathrm{OP}$ tree covers. $\mathrm{N}$ was higher at $0-5 \mathrm{~cm}$ soil depth. The $\mathrm{pH}$ was nonsignificantly different for tree cover factor, it showed moderately acidic values, and it was more acid at $0-5 \mathrm{~cm}$, characteristic at soil with higher SOC (Potthast et al., 2017).

Our SOC results were similar to those reported by Dube and Stolpe (2016), in a study of Andean and Coastal $N$. obliqua forests under different degradation levels in the Biobío Region of Chile. In their study, SOC in the coastal area was significantly higher $(\mathrm{P}<0.05)$ in the non-degraded than in the degraded forests, and a tended to be higher under non-degraded conditions. Our results indicated that SOC and N was sensitive to the tree cover level, that can be attributed to the differences in the frequency or intensity of historical logging, cattle browsing and grazing processes in the three tree covers, where the forest with OP cover has been the most disturbed. These processes can modify the tree covers and the vegetation of the study sites. Forest degradation by deforestation, grazing, and

Table 2. P values for chemical, biological and biochemical parameters.

\begin{tabular}{lcccccccc}
\hline & \multicolumn{7}{c}{ P value } \\
\cline { 2 - 8 } Source of variation & SOC & $\mathrm{N}$ & $\mathrm{C} / \mathrm{N}$ & $\mathrm{pH}$ & $\mathrm{SMR}$ & $\mathrm{MBC}$ & $\mathrm{N}-\mathrm{min}$ & $\mathrm{N}-\mathrm{NO} \mathrm{O}_{3}$ \\
\hline Tree cover & $\mathbf{0 . 0 0 1}$ & $\mathbf{0 . 0 2}$ & 0.15 & 0.31 & $\mathbf{< 0 . 0 0 0 1}$ & $<\mathbf{0 . 0 0 0 1}$ & $<\mathbf{0 . 0 0 0 1}$ & $<\mathbf{0 . 0 0 0 1}$ \\
Soil depth & $<\mathbf{0 . 0 0 0 1}$ & $<\mathbf{0 . 0 0 0 1}$ & 0.06 & $\mathbf{0 . 0 0 0 1}$ & $<\mathbf{0 . 0 0 0 1}$ & $<\mathbf{0 . 0 0 0 1}$ & $<\mathbf{0 . 0 0 0 1}$ & $\mathbf{0 . 0 1}$ \\
Cover $\times$ Depth & 0.96 & 0.91 & 0.17 & 0.17 & $\mathbf{0 . 0 0 3}$ & $\mathbf{0 . 0 0 3}$ & $<\mathbf{0 . 0 0 0 1}$ & $<\mathbf{0 . 0 0 0 1}$ \\
\hline
\end{tabular}

SOC: Soil organic C, SMR: soil microbial respiration, MBC: microbial biomass $\mathrm{C}, \mathrm{N}$-min: potential net $\mathrm{N}$ mineralization, $\mathrm{N}-\mathrm{NO}_{3}$ : potential net nitrification. Bold values are significant.

Table 3. Soil organic $\mathrm{C}, \mathrm{N}$, and $\mathrm{pH}$ for each tree cover and soil depth.

\begin{tabular}{lccc}
\hline & & \multicolumn{2}{c}{ Soil depth } \\
\cline { 3 - 4 } Variable & Tree cover & $0-5 \mathrm{~cm}$ & $5-20 \mathrm{~cm}$ \\
\hline SOC $(\%)$ & PC & $10.54 \pm 0.42 \mathrm{aA}$ & $7.17 \pm 0.60 \mathrm{aB}$ \\
& PO & $9.37 \pm 0.48 \mathrm{bA}$ & $6.33 \pm 0.39 \mathrm{aB}$ \\
& OP & $9.40 \pm 0.51 \mathrm{bA}$ & $6.27 \pm 0.21 \mathrm{aB}$ \\
$\mathrm{N}(\%)$ & PC & $0.58 \pm 0.03 \mathrm{aA}$ & $0.36 \pm 0.05 \mathrm{aB}$ \\
& PO & $0.54 \pm 0.05 \mathrm{aA}$ & $0.32 \pm 0.07 \mathrm{aB}$ \\
& OP & $0.48 \pm 0.05 \mathrm{aA}$ & $0.27 \pm 0.06 \mathrm{aB}$ \\
$\mathrm{pH}\left(\mathrm{H}_{2} \mathrm{O}\right)$ & PC & $5.9 \pm 0.1 \mathrm{aA}$ & $6.2 \pm 0.1 \mathrm{aB}$ \\
& PO & $6.0 \pm 0.2 \mathrm{aA}$ & $6.2 \pm 0.2 \mathrm{aB}$ \\
& OP & $5.8 \pm 0.2 \mathrm{aA}$ & $6.3 \pm 0.2 \mathrm{aB}$ \\
\hline
\end{tabular}

Values with the same lower-case letter within a column are not different according to Tukey's test $(\mathrm{P}<0.05)$.

Values with the same uppercase letter within the $0-5$ and $5-20 \mathrm{~cm}$ soil depths and a same tree cover are not different according to Student's t test $(\mathrm{P}<0.05)$. Mean \pm standard deviation. PC: Partly-closed, PO: partly-open, OP: open tree cover, SOC: soil organic C. 
erosion can modify soil $\mathrm{C}$ stock because of interactions between quantity and quality of organic residues entering the soil and their subsequent use by soil macro and microorganisms, this affects the net SOM accumulation rate (Dube and Stolpe, 2016; Wang et al., 2017). In our case, a higher leaf litter contribution can accumulate in the soil in the ecosystem with the largest tree cover (PC) compared to the other two smaller covers (PO and OP). Lillo et al. (2011) found similar results when comparing different tree communities in southern Chile and determined that the higher plant cover (in both tree and shrub strata) allows higher SOM accumulation.

The tendency presented by our data is that higher SOC was recorded at the $0-5 \mathrm{~cm}$ soil depth (Table 3); SOC is usually closely related to larger OM content accumulated in the upper layer of the soil. Dube et al. (2009), who studied a Nothofagus pumilio (Poepp. \& Endl.) Krasser, forest in Chilean Patagonia, indicate that superficial OM was less resistant to microbial decomposition than OM in lower soil layers, therefore, contents of SOC are higher.

The soil C stocks calculated at the 0-20 cm depth were 129, 128, and $145 \mathrm{Mg} \mathrm{ha}^{-1}$ for OP, PO, and PC forest conditions, respectively. Our results were similar to those obtained by Huygens et al. (2005), who reported $132 \mathrm{Mg}$ SOC ha ${ }^{-1}$ in Andisols at the 0-30 cm depth in second-growth N. obliqua forests, and Dube and Stolpe (2016) that indicate values for $N$. obliqua forests in the Biobío Region at the 0-40 cm depth for degraded, partially-degraded, and non-degraded Andean forests were 129, 117, and $176 \mathrm{Mg} \mathrm{SOC} \mathrm{ha}^{-1}$, respectively, and values for degraded, partially-degraded, and non-degraded coastal forests were 144, 134, and $162 \mathrm{Mg} \mathrm{SOC} \mathrm{ha}^{-1}$, respectively. According to Dube and Stolpe (2016), soil C calculation depends on variables such as C concentration, horizon thickness, and bulk density, all of which have their respective variations and errors.

\section{Biological parameters}

The tree cover and soil depth presented a significant effect on SMR and MBC (Table 2). In addition, Tree cover $\times$ Soil depth interaction was recorded $(\mathrm{P}<0.05)$ (Figure 2).

According with the Tree cover $\times$ Soil depth interaction, SMR and MBC variables did not behave in the same way in the three tree covers, and the behavior of levels of cover depends on the levels of the depth with which it is combined. The Figures $2 \mathrm{~A}$ and $2 \mathrm{~B}$ indicated for SMR and MBC that the simple effect of soil depth in PC cover differs from both the simple effect of soil depth in OP and PO cover, and the simple effect of soil depth in OP cover does not differ from the simple effect of soil depth in PO cover. A contrasts analysis for the interaction indicated that SMR and MBC in PC cover differ of PO and OP covers at the $0-5 \mathrm{~cm}$ soil depth, were approximately $12 \%$ higher.

SMR and MBC are strongly sensitive to the amount of substrate available, regarding cover probably due to the difference in the quantity and quality of substrates entering the soil (litter), and in soil depth due to the availability of substrates; the upper soil layer contains more available substrate for the microorganisms are more active, which coincides with higher SOC levels (Dube et al., 2009; Ferreras et al., 2009). This behavior can be attributable to the less disturbed forest conditions in the PC cover with respect to the other covers, due to a lower frequency or intensity of logging or cattle grazing in this forest (Dube et al., 2016). The greater number of trees and vegetation in PC cover, which may allow a greater accumulation of OM in the soil, favoring the rates of SMR and MBC. Bown et al. (2014), studied soil respiration along a gradient of disturbances in sclerophyllous ecosystems in the Roblería

Figure 2. Soil microbial respiration and microbial biomass $\mathrm{C}$ for each tree cover and soil depth.
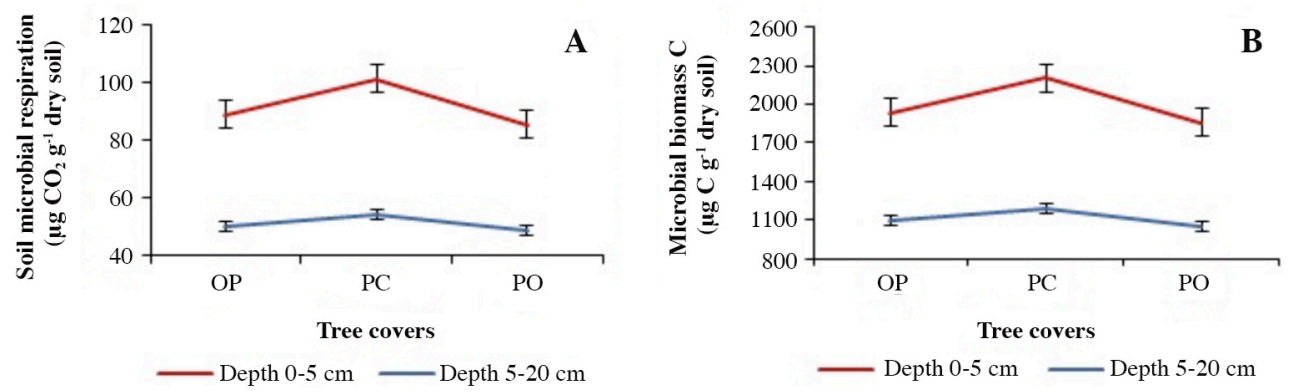

A: Means and interaction for soil microbial respiration, B: Means and interaction for microbial biomass C. OP: Open, PC: partly-closed, PO: partly-open tree covers. 
del Cobre de Loncha National Reserve in central Chile; they found that the disturbances presumably decreased soil respiration rates mediated by reductions in the leaf litter layer, SOM, root biomass, and water content, especially in the hot and dry season. Wang et al. (2017) indicates that soil biota is influenced by the quality and quantity of plant material provided to the soil, and climatic characteristics that also affect microbial abundance, involved species, and its trophic composition.

The results that we obtained for MBC in the PC tree cover are very similar to values reported by Alvear et al. (2007) for the spring season in a N. obliqua forest with approximately $78 \%$ of tree cover. Our results are higher than those found by Lillo et al. (2011) for N. alpina (Poepp. \& Endl.) Oerst.-N. dombeyi (Mirb.) Blume tree community in southern Chile. Our results for SMR and MBC are lower than values recorded by Dube et al. (2009) in a secondary N. pumilio forest in the Chilean Patagonia. The differences can be attributable to the different quality (chemical and physical leaf composition between deciduous and perennial trees), distribution of available substrates in different ecosystems, and different laboratory methods (Dube et al., 2009; Zagal et al., 2009).

\section{Potential net $\mathbf{N}$ mineralization ( $\mathrm{N}-\mathrm{min})$ and nitrification $\left(\mathrm{N}-\mathrm{NO}_{3}\right)$}

The tree cover and soil depth had a significant effect on the $\mathrm{N}$-min, and $\mathrm{N}^{-\mathrm{NO}_{3}}$ (Table 2). The analysis showed interaction between these factors $(\mathrm{P}<0.05)$ (Figure 3).

The N-min and $\mathrm{N}^{-\mathrm{NO}_{3}}$ values that we determined (Figure 3), concurred with the annual ranges reported by Rivas et al. (2009) (-3.47 to $7.98 \mu \mathrm{g} \mathrm{N} \mathrm{g}^{-1}$ dry soil d ${ }^{-1}$ and -2.6 to $3.75 \mu \mathrm{g} \mathrm{N}-\mathrm{NO}_{3} \mathrm{~g}^{-1}$ dry soil $\mathrm{d}^{-1}$ ), who presented higher rates in summer and autumn at the $0-10 \mathrm{~cm}$ depth in a secondary $N$. obliqua forest in south central Chile. Our results also coincided with those found by Pérez et al. (2009) at 0-10 cm depth in Nothofagus forests in Chiloé, Chile, with maximum rates of $\mathrm{N}$-min of $6.00 \mu \mathrm{g} \mathrm{N} \mathrm{g}^{-1}$ dry soil $\mathrm{d}^{-1}$ in field and laboratory incubations; they also indicated that $\mathrm{N}-\mathrm{NO}_{3}$ was approximately $50 \%$ of total $\mathrm{N}$-min. The higher $\mathrm{N}$ content (Table 3), coincided with higher $\mathrm{N}$-min, SOC, and MBC values. This is in agreement with Rivas et al. (2009), who indicate for two Nothofagus forests, that the higher biological activity of the soil promotes the processes of $\mathrm{N}$ mineralization.

The interaction Tree cover $\times$ Soil depth indicated for the $\mathrm{N}$-min and $\mathrm{N}^{-\mathrm{NO}_{3}}$ that the effect of depth is not the same in the three tree covers (Figures $3 \mathrm{~A}$ and $3 \mathrm{~B}$ ). A contrasts analysis for the interaction indicated that N-min and $\mathrm{N}-\mathrm{NO}_{3}$ presented the behavior: $\mathrm{PC}>\mathrm{PO}>\mathrm{OP}$, in both soil depth. At the $0-5 \mathrm{~cm}$ soil depth $\mathrm{N}$-min was $68 \%$ and $95 \%$ higher than in $\mathrm{PO}$ and $\mathrm{OP}$ covers, respectively. For the same soil depth $\mathrm{N}^{-\mathrm{NO}_{3}}$ in $\mathrm{PC}$ cover was $45 \%$ higher than the PO cover. This behavior indicated that the higher alterations of the forest, probably due to the different intensities of logging or cattle grazing and cover tree reduction, can have a negative impact on $\mathrm{N}$-min and $\mathrm{NO}_{3}$, possibly due to the reduction of residues that enter the soil, and the $\mathrm{N}$ usable by plants and microorganisms accumulates in the organic horizons, where humification processes are most active, and markedly decreases with soil depth (Trap et al., 2009). Pérez et al. (2009) indicate that the $\mathrm{N}$ mineralization processes in forest soils in Chiloé, are correlated with high soil biological activity, higher labile inorganic $\mathrm{N}$ content, and increased entry of fine leaf litter. In the southeastern Argentinean Patagonia, it was determined that N. antarctica (G. Forst.) Oerst. forest thinning practices for silvopasture (maintaining intermediate canopy cover values) did not affect either $\mathrm{N}$-min or $\mathrm{N}-\mathrm{NO}_{3}$. However,

Figure 3. Potential net $\mathrm{N}$ mineralization and nitrification for each tree cover and soil depth.
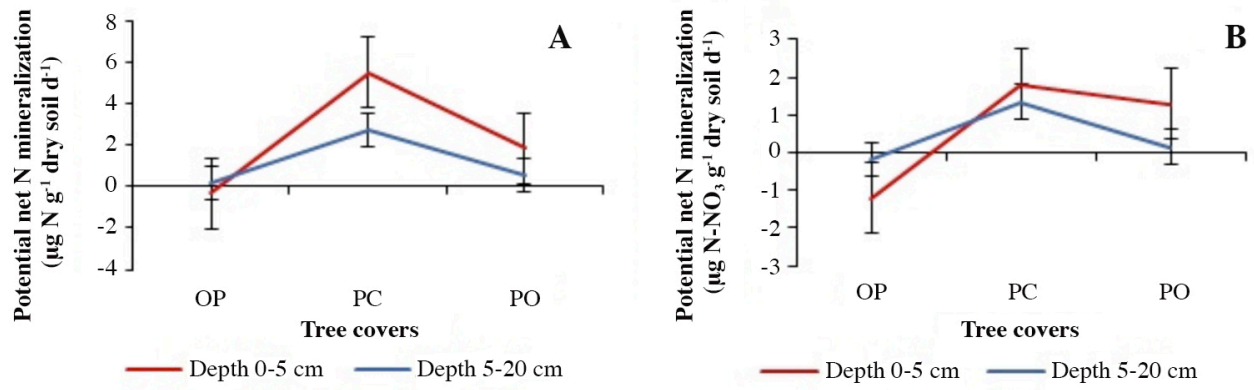

A: Means and interaction for potential net $\mathrm{N}$ mineralization, B: Means and interaction for potential net nitrification.

OP: Open, PC: partly-closed, PO: partly-open tree covers. 
the lowest $\mathrm{N}$-min and $\mathrm{N}-\mathrm{NO}_{3}$ values were found in a treeless site, suggesting that the total removal of trees from the ecosystem can reduce $\mathrm{N}-$ min and $\mathrm{N}-\mathrm{NO}_{3}$ (Bahamonde et al., 2013).

We recorded negative $\mathrm{N}-$ min and $\mathrm{N}-\mathrm{NO}_{3}$ values in the OP tree cover (Figure 3). N-min and $\mathrm{N}-\mathrm{NO}_{3}$ negative values indicate that $\mathrm{N}$ is not potentially available for use by plants and soil microorganisms, and indicate net immobilization. Mineralization results in an increase, while immobilization results in a decrease in the simple forms of $\mathrm{N}$ in the soil available to plants (Rivas et al., 2009). Net mineralization occurs when the total amount of soluble $\mathrm{N}$ produced by microorganisms (gross mineralization) exceeds the total amount of soluble $\mathrm{N}$ consumed (gross immobilization), and consequently the inorganic $\mathrm{N}$ in the soil increases. When the amount of soluble $\mathrm{N}$ consumed is greater than the soluble $\mathrm{N}$ produced, the inorganic $\mathrm{N}$ in the soil decreases, that is, there is net immobilization (Trap et al., 2009). The organic matter quality (C availability in the material in relation to its available $\mathrm{N}$ ) is the main factor that controls the equilibrium between mineralization and immobilization (Tian et al., 2017).

Nitrogen limits plant growth in most terrestrial ecosystems; therefore, net primary production (productive capacity) can be regulated by the rates at which soil microbes transform $\mathrm{N}$ to make it available for plants (Tian et al., 2017). According to our results we could infer that the alteration of the forest by uncontrolled processes of logging or cattle grazing, and the tree cover modification can affect the quantity and quality of the substrates that enter in the soil, and $\mathrm{N}$ dynamics. The logging reduces the amount of trees and vegetation, and overgrazing can effect regeneration processes and soil structure (Bahamonde et al., 2013; Dube and Stolpe, 2016).

\section{Physical fractionation of SOM}

The soil fraction had a significant effect on the dry weight of soil fractions, and this variable presented Cover $\times$ Fraction interaction (Table 4). Tree cover, soil depth and soil fraction had a significant effect on the organic $\mathrm{C}$ and $\mathrm{N}$ content. Organic $\mathrm{C}$ content presented interaction for Cover $\times$ Fraction, and Depth $\times$ Fraction. $\mathrm{N}$ content presented Cover $\times$ Fraction interaction $(\mathrm{P}<0.05)($ Table 4$)$.

The Cover $\times$ Fraction interaction for dry weight of soil fractions indicated that this variable is sensitive to the distribution by fraction. A contrast analysis for the interaction indicated that in each covers, dry weight of soil fractions were dominated by the microaggregates, followed by mesoaggregates, macroaggregates, and finally the LF (Figure 4 A). This is concurring with the results reported by Dube et al. (2009) for a secondary N. pumilio forest, and Dube and Stolpe (2016) in a study of different degradation levels of a N. obliqua forest. A contrast analysis for the interaction indicated that the LF fraction (labile OM) in OP cover was 90 and 67\% lower respect PC and PO covers, respectively. Likewise, the macroaggregates (labile OM) in OP cover was 55\% lower than the PC and PO covers. This can be due to a higher contribution of leaf litter and fine roots at soil in the covers with more trees covers. Gosling et al. (2013), using data from more than 150 experiments reported in the literature, mention that the LF is strongly influenced by factors related to the recent history of adding OM to the soil. LF is a thick and unstable OM, so that its content in the soil tends to be affected by rapid changes that is, influenced by the historical management of soil and forest (Huygens et al., 2005; Dube et al., 2009). The historical processes of logging and cattle grazing with possible greater frequency or intensity in OP cover, could cause less accumulation of OM in the soil, and lost in the physical protection, contributing to the loss of SOM labile (Chen et al., 2017).

Table 4. P values for dry weight of soil fractions, and organic $\mathrm{C}$ and $\mathrm{N}$ content in the soil fractions.

\begin{tabular}{lccc}
\hline & \multicolumn{3}{c}{ P value } \\
\cline { 2 - 4 } Source of variation & Dry weight & Organic C & N content \\
\hline Tree cover & 0.86 & $\mathbf{< 0 . 0 0 0 1}$ & $<\mathbf{0 . 0 0 0 1}$ \\
Soil depth & 0.95 & $<\mathbf{0 . 0 0 0 1}$ & $<\mathbf{0 . 0 0 0 1}$ \\
Soil fraction & $<\mathbf{0 . 0 0 0 1}$ & $\mathbf{< . 0 0 0 1}$ & $<\mathbf{0 . 0 0 0 1}$ \\
Cover $\times$ Depth & 0.95 & 0.72 & 0.11 \\
Cover $\times$ Fraction & $<\mathbf{0 . 0 0 0 1}$ & $\mathbf{< 0 . 0 0 0 1}$ & $\mathbf{0 . 0 4}$ \\
Depth $\times$ Fraction & 0.06 & $<\mathbf{0 . 0 0 0 1}$ & 0.22 \\
Cover $\times$ Depth $\times$ Fraction & 0.06 & 0.34 & 0.49 \\
\hline
\end{tabular}

Bold values are significant. 
Figure 4. Dry weight of soil fractions, and organic $\mathrm{C}$ and $\mathrm{N}$ content in the different soil fractions for each tree cover and soil depth.
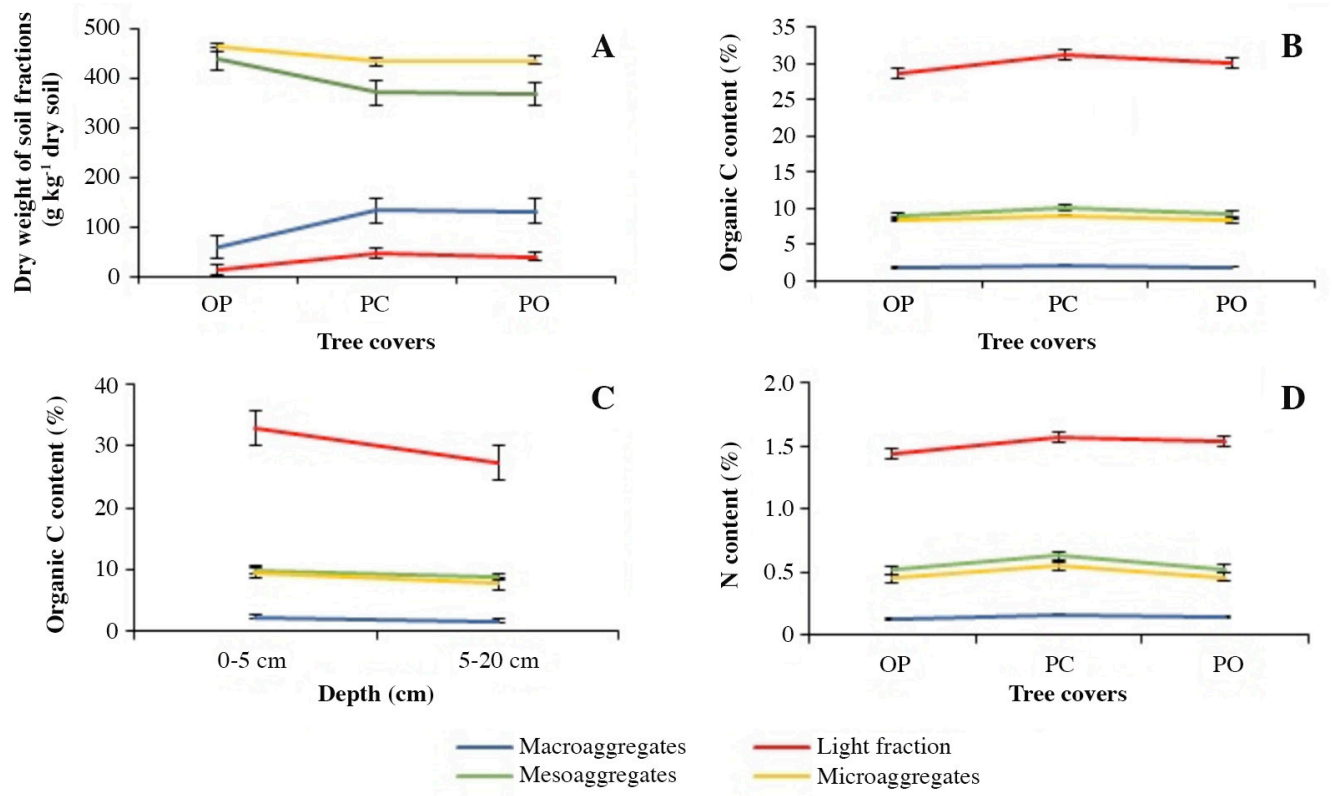

A: Means and interaction for dry weight of soil fractions, B: Means and interaction for organic C content in each tree cover, C: Means and interaction for organic C content in each soil depth, D: Means and interaction for $\mathrm{N}$ content.

OP: Open, PC: partly-closed, PO: partly-open tree covers.

Our results indicated a LF quantity between 10 and $60 \mathrm{~g} \mathrm{LF} \mathrm{kg}^{-1}$ dry soil (Figure 4A), these values concur with results reported by Huygens et al. (2005) for a secondary N. obliqua forest. Gosling et al. (2013) mention the importance that amount and composition of LF organic matter could play an important role in $\mathrm{N}$ dynamics and $\mathrm{C}$, and retention in the soil. Lower LF values in the OP cover probably contributed to lower values in SOC, MBC, $\mathrm{N}-$ min and $\mathrm{N}-\mathrm{NO}_{3}$ in this tree cover.

The Cover $\times$ Fraction interaction for organic $\mathrm{C}$ and $\mathrm{N}$ content in the soil fraction indicated that these contents were sensitive to the cover level (soil use) and the frequency or intensity of logging and grazing practices (Figure 4 $\mathrm{B}$ and D). The interaction Depth $\times$ Fraction indicated that organic C content is sensitive to soil depth, or pedogenic or environmental characteristics between soil depths (Figure 4C) (Zagal et al., 2013; Chen et al., 2017).

For the three tree covers, LF fraction presented the higher values of $\mathrm{C}$ and $\mathrm{N}$ content, followed by the mesoaggregates, microaggregates and finally the macroaggregates (Figures 4B and 4D). This happens because LF is formed by undecomposed $\mathrm{OM}$ of plant origin, and in the stable fractions the OM is incorporated to the soil (Zagal et al., 2013).

The organic C contents in the different fractions are similar to those reported by Huygens et al. (2005) for a secondary N. obliqua forest, by Dube et al. (2009) for a N. pumilio forest, and Dube and Stolpe (2016) for N. obliqua forest.

\section{CONCLUSIONS}

Soil quality and microbial activity were affected by the alteration of the tree cover in Nothofagus obliqua forests, as well by the anthropic action of selective logging and extensive cattle browsing and grazing with the site natural vegetation. The soil quality indicators evaluated at 0-5 and 5-20 cm soil depths were higher in the partly-closed cover and lower in the open cover.

The alteration of tree covers showed an important variation in the different analyzed soil quality indices, particularly in $\mathrm{N}$ dynamics and light fraction. Differences in quality and quantity of the substrate (soil organic matter input, leaf litter accumulation), and distribution of $\mathrm{C}$ supply to the ecosystem, likely a result of differences in logging and grazing frequency or intensity, can explain this behavior. 
The light fraction was the most important measured sink for $\mathrm{N}$ and $\mathrm{C}$ in the soil aggregates. The amount and composition of the light fraction organic matter could play an important role in $\mathrm{N}$ and $\mathrm{C}$ dynamics, and retention in the soil.

The significant interactions Cover $\times$ Depth for soil microbial respiration, microbial biomass $\mathrm{C}$, potential net $\mathrm{N}$ mineralization, and nitrification, and Cover $\times$ Fraction for dry weight of soil fractions, organic $\mathrm{C}$ and $\mathrm{N}$ content in the different soil fractions, indicated that these parameters were sensitive to the tree cover level (soil use), frequency or intensity of logging and grazing, and the pedogenic or environmental differences between soil depths.

\section{ACKNOWLEDGEMENTS}

This study was partially funded by the Native Forest Research Fund of the National Forestry Corporation, Chile (FIBN-CONAF Project $\mathrm{N}^{\circ}$ 001-2014). We wish to acknowledge the Universidad de Costa Rica, and CONICIT Costa Rica for the scholarships for doctoral studies.

\section{REFERENCES}

Alef, K. 1995. Nitrogen mineralization in soils. p. 234-245. In Alef, K., and Nannipieri, P. (eds.) Methods in applied soil microbiology and biochemistry. Academic Press, London, UK.

Altamirano, A., y Lara, A. 2010. Deforestación en ecosistemas templados de la precordillera andina del centro-sur de Chile. Bosque 31:53-64.

Alvear, M., Urra, C., Huaiquilao, R., Astorga, M., y Reyes, F. 2007. Actividades biológicas y estabilidad de agregados en un suelo del bosque templado chileno bajo dos etapas sucesionales y cambios estacionales. Revista de la Ciencia del Suelo y Nutrición Vegetal 7:38-50.

Anderson, J.P., and Domsch, K.H. 1978. A physiological method for the quantitative measurement of microbial biomass in soils. Soil Biology and Biochemistry 10:215-221.

Annighöfer, P., P. Beckschäfer, T. Vor, and C. Ammer. 2015. Regeneration patterns of European oak species (Quercus petraea (Matt.) Liebl., Quercus robur L.) in dependence of environment and neighborhood. PLOS ONE 10:e0134935.

Bahamonde, H., Peri, P., Alvarez, R., Barneix, A., Moretto, A., and Martínez Pastur, G. 2013. Silvopastoral use of Nothofagus antarctica in Southern Patagonian forests, influence over net nitrogen soil mineralization. Agroforestry Systems 87:259-271.

Bastida, F., Zsolnay, A., Hernández, T., and García, C. 2008. Past, present and future of soil quality indices: A biological perspective. Geoderma 147:159-171.

Bergh, G., y Promis, A. 2011. Conservación de los bosques nativos de Chile. Un análisis al informe FAO sobre la evaluación de los recursos forestales nacionales. Revista Bosque Nativo 48:9-11.

Bown, H.E., Fuentes, J.P., Perez-Quezada, J.F., y Franck, N. 2014. Soil respiration across a disturbance gradient in sclerophyllous ecosystems in Central Chile. Ciencia e Investigación Agraria: Revista Latinoamericana de Ciencias de la Agricultura 41:89-106.

CIREN. 1999. Estudio agrológico VIII Región. Descripciones de suelos. Materiales y símbolos. Publicación CIREN N ${ }^{\circ}$ 121 Vol. 2.586 p. Centro de Información de Recursos Naturales, (CIREN), Santiago, Chile.

Chen, Z., Geng, S., Zhang, J., Setälä, H., Gu, Y., Wang, F., et al. 2017. Addition of nitrogen enhances stability of soil organic matter in a temperate forest. European Journal of Soil Science 68:189-199.

Donoso, C., Grez, R., Escobar, B., y Real, P. 1984. Estructura y dinámica de bosques del tipo forestal siempreverde en un sector de Chiloé insular. Bosque 5:82-104.

Dube, F., Sotomayor, A., Loewe, V., Müller-Using, B., Stolpe, N., Zagal, E., et al. 2016. Silvopastoral systems in temperate zones of Chile. p. 183-230. In Peri, P.L., Dube, F., and Varella, A. (eds.) Advances in agroforestry-silvopastoral systems in southern South America. Springer International Publishing, Gewerbestrasse, Switzerland.

Dube, F., and Stolpe, N. 2016. SOM and biomass C stocks in degraded and undisturbed Andean and Coastal Nothofagus forests of Southwestern South America. Forests 7:320-340.

Dube, F., Zagal, E., Stolpe, N., and Espinosa, M. 2009. The influence of land-use change on the organic carbon distribution and microbial respiration in a volcanic soil of the Chilean Patagonia. Forest Ecology and Management 257:1695-1704.

Feller, C., Burtin, G., Gerard, B., et Balesdent, J. 1991. Utilisation des résines sodiques et des ultrasons dans le fractionnement granulométrique de la matière organique des sols. Intérêt et limites. Science du Sol 29:77-94.

Ferreras, L., Toresani, S., Bonel, B., Fernández, E., Bacigaluppo, S., Faggioli, V., et al. 2009. Parámetros químicos y biológicos como indicadores de calidad del suelo en diferentes manejos. Ciencia del Suelo 27:103-114. 
Garrido, E., and F. Matus. 2012. Are organo-mineral complexes and allophane content determinant factors for the carbon level in Chilean volcanic soils? CATENA 92:106-112.

Gosling, P., Parsons, N., and Bending, G.D. 2013. What are the primary factors controlling the light fraction and particulate soil organic matter content of agricultural soils? Biology and Fertility of Soils 49:1001-1014.

Huygens, D., Boeckx, P., Van Cleemput, O., Oyarzún, C., and Godoy, R. 2005. Aggregate and soil organic carbon dynamics in South Chilean Andisols. Biogeosciences 2:159-174.

Lara, A., Little, C., Urrutia, R., McPhee, J., Álvarez-Garretón, C., Oyarzún, C., et al. 2009. Assessment of ecosystem services as an opportunity for the conservation and management of native forests in Chile. Forest Ecology and Management 258:415-424.

Lillo, A., Ramírez, H., Reyes, F., Ojeda, N., y Alvear, M. 2011. Actividad biológica del suelo de bosque templado en un transecto altitudinal, Parque Nacional Conguillío ( $\left.38^{\circ} \mathrm{S}\right)$, Chile. Bosque 32:46-56.

Linn, D., and Doran, J. 1984. Effect of water-filled pore space on carbon dioxide and nitrous oxide production in tilled and nontilled soils. Soil Science Society of America Journal 48:1267-1272.

Paul,E. 2016. The nature and dynamics of soil organic matter: Plant inputs, microbial transformations, and organic matter stabilization. Soil Biology and Biochemistry 98:109-126.

Pérez, C., Carmona, M., Farina, J., and Armesto, J. 2009. Selective logging of lowland evergreen rainforests in Chiloe Island, Chile: Effects of changing tree species composition on soil nitrogen transformations. Forest Ecology and Management 258:1660-1668.

Potthast, K., Meyer, S., Crecelius, A.C., Schubert, U.S., Tischer, A., and Michalzik, B. 2017. Land-use and fire drive temporal patterns of soil solution chemistry and nutrient fluxes. Science of the Total Environment 605:514-526.

Rivas, Y., Oyarzún, C., Godoy, R., y Valenzuela, E. 2009. Mineralización del nitrógeno, carbono y actividad enzimática del suelo en un bosque de Nothofagus obliqua (Mirb) Oerst. y una plantación de Pinus radiata D. Don. del centro-sur de Chile. Revista Chilena de Historia Natural 82:119-134.

Sadzawka, A., Carrasco, M., Grez, R., Mora, M., y Flores, H. 2006. Métodos de análisis recomendados para los suelos de Chile. Revisión 2006. Instituto de Investigaciones Agropecuarias INIA, Santiago, Chile.

Stolpe, N., and Undurraga, P. 2016. Long term climatic trends in Chile and effects on soil moisture and temperature regimes. Chilean Journal of Agricultural Research 76:487-496.

Tian, D., Jiang, L., Ma, S., Fang, W., Schmid, B., Xu, L., et al. 2017. Effects of nitrogen deposition on soil microbial communities in temperate and subtropical forests in China. Science of the Total Environment 607:1367-1375

Trap, J., Bureau, F., Vinceslas-Akpa, M., Chevalier, R., and Aubert, M. 2009. Changes in soil N mineralization and nitrification pathways along a mixed forest chronosequence. Forest Ecology and Management 258:1284-1292.

Wang, J.-J., Pisani, O., Lin, L.H., Lun, O.O.Y., Bowden, R.D., Lajtha, K., et al. 2017. Long-term litter manipulation alters soil organic matter turnover in a temperate deciduous forest. Science of the Total Environment 607:865-875.

Wright, A.F., and Bailey, J.S. 2001. Organic carbon, total carbon, and total nitrogen determinations in soils of variable calcium carbonate contents using a Leco CN-2000 dry combustion analyzer. Communications in Soil Science and Plant Analysis 32:3243-3258.

Zagal, E., Córdova, C., Sohi, S., and Powlson, D. 2013. Free and intra-aggregate organic matter as indicators of soil quality change in volcanic soils under contrasting crop rotations. Soil Use and Management 29:531-539.

Zagal, E., Muñoz, C., Quiroz, M., and Córdova, C. 2009. Sensitivity of early indicators for evaluating quality changes in soil organic matter. Geoderma 151:191-198. 